\title{
Aspects of fishing and reproduction of the black grouper Mycteroperca bonaci (Poey, 1860) (Serranidae: Epinephelinae) in the Northeastern Brazil
}

\author{
Simone Ferreira Teixeira*, Beatrice Padovani Ferreira* \\ and Isaíras Pereira Padovan**
}

The reproductive biology of the black grouper Mycteroperca bonaci, caught by artisanal fishermen using hook and line or compressor - assisted spear fishing, from the Northeastern shelf and oceanic banks of Brazil, was studied between August 1996 and April 1998. The sexual pattern, gonadal development, the spawning mode and seasonality were investigated. The gonadal stages indicated that this species is a protogynous hermaphrodite and that transition from female to male occurs through simultaneous re-absorption of ovarian tissue and proliferation of testicular tissue in the gonads. The specie is a multiple spawner and frequency analysis of gonadal stages and gonadosomatic index suggest that the spawning season occurs between April and September. Considerations about the fisheries, related to size structure of fishes caught, were based on length frequency distribution. The phenomenon of "correção" was described based on ethnobiology studies and informations from the Northeast Fisheries Statistics Bulletin of the Brazilian Environmental Institute (IBAMA). The phenomenon of the "correção" undergone by Mycteroperca bonaci seems to be a Southward chain reaction (of the State of Ceará to Bahia) and is a feeding aggregation.

A biologia reprodutiva do sirigado Mycteroperca bonaci, capturado na pesca artesanal com uso de linha e arpão, na plataforma e bancos oceânicos do nordeste do Brasil, foi estudada entre agosto de 1996 e abril de 1998. O padrão sexual, o desenvolvimento gonadal e o modo e período de desova foram investigados. Os estágios gonadais indicam que esta espécie é hermafrodita protogínica e que a transição de fêmea para macho ocorre simultaneamente através da reabsorção do tecido ovariano e da proliferação do tecido testicular nas gônadas. A espécie apresenta desova múltipla e a análise da freqüência dos estágios gonadais e do índice gonadassomático sugerem que a desova ocorre entre abril e setembro. Considerações sobre a pesca, relacionada à estrutura de tamanho dos peixes capturados, foram baseadas na distribuição de freqüência de comprimentos. O fenômeno da correção foi descrito baseado em estudos etnobiológicos e informações dos Boletins Estatísticos da Pesca do Instituto Brasileiro do Meio Ambiente e dos Recursos Naturais Renováveis (IBAMA). A correção realizada por Mycteroperca bonaci parece ser um efeito em cadeia, que inicia no norte (Ceará) e termina no sul (Bahia), e corresponde a uma agregação alimentar.

Key words: Serranid, reproductive biology, protogynous hermaphrodite, "correção", feeding aggregation.

\section{Introduction}

The reproductive biology and ecology of exploited reef fish species have received little attention when compared to other aspects of their natural history. This lack of emphasis has been exacerbated by the difficulties of studying larger species in the field. Access to samples, restricted opportunities for direct observations, limitations of research funding and inadequate facilities in many tropical areas, have hampered biological studies of larger commercially important reef associated fishes (Sadovy, 1996).

Although most teleosts are gonochoristic, a growing

\footnotetext{
* Departamento de Oceanografia, Universidade Federal de Pernambuco, Av. Arquitetura s/n, 50670-901 Pernambuco, Brazil e-mail: sfteixeira@bol.com.br

** Departamento de Histologia e Embriologia, Universidade Federal de Pernambuco, Av. Prof. Moraes Rego, s/n, 50670-420 Pernambuco, Brazil.
} 


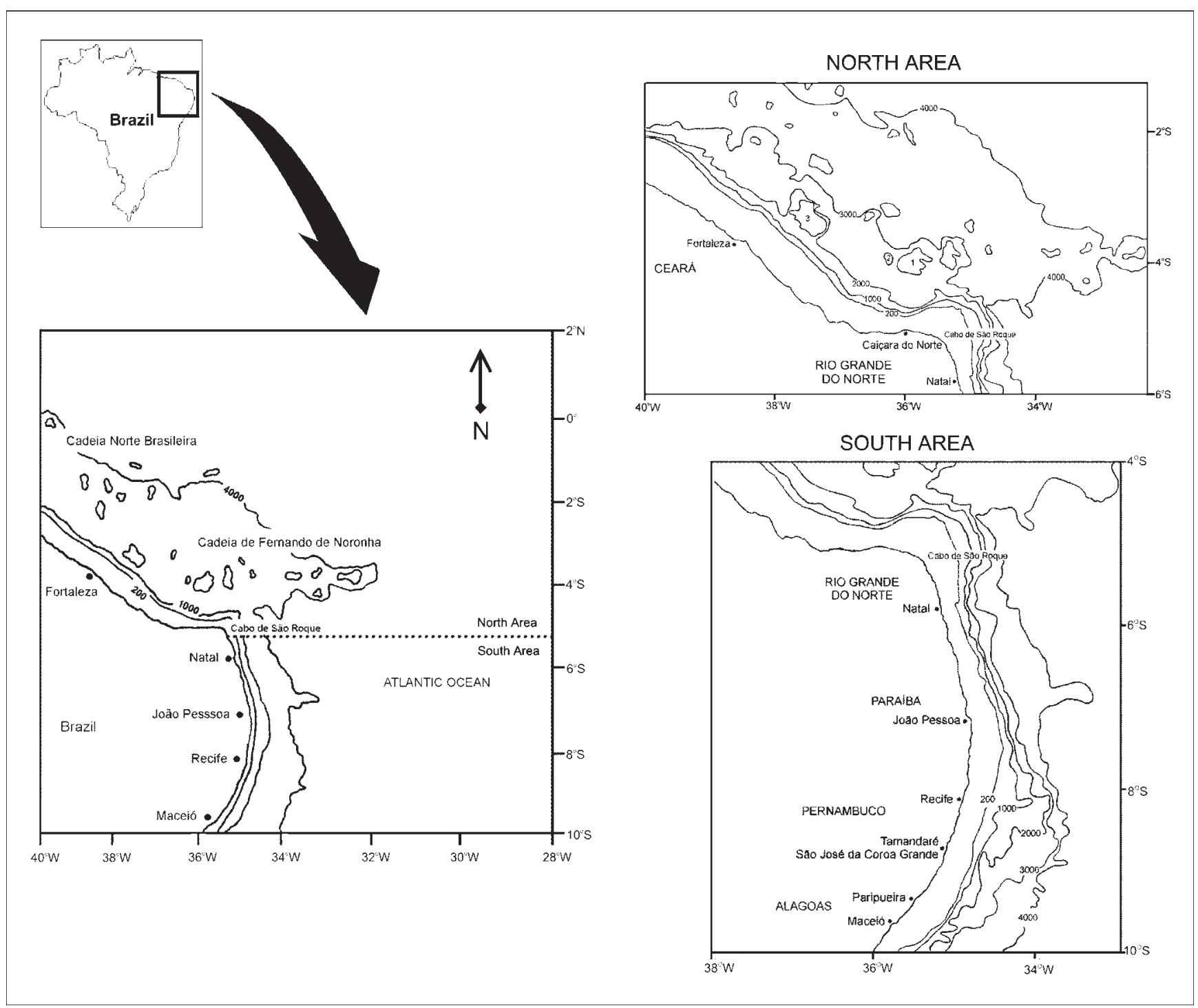

Fig. 1. Sampling area (adapted from the Nautical Charts no. 50 and 60 of Diretoria de Hidrografia e Navegação - Brazilian Navy). Upper right: details of the North area, 1 - Sirius Bank, 2 - Guará Bank, 3 - Aracati Bank. Bottom right: details of the South area.

number of hermaphroditic species are being detected. The Serranid fishes include many hermaphroditic species and exhibit a range of sexual patterns (Sadovy \& Colin, 1995).

The black grouper Mycteroperca bonaci (Poey, 1860) is a large serranid and is found in reef habitats from Bermuda and Massachusetts to Southeastern Brazil, including the Southern Gulf of Mexico, the Florida Keys, Bahamas, Cuba and the Caribbean (Heemstra \& Randall, 1993). Smith (1965), GarcíaCagide \& García (1996) and Crabtree \& Bullock (1998) reported protogynous hermaphroditism in $M$. bonaci. Diagnosis of protogynous hermaphroditism depends on identifying characteristics that involve gonadal histology, among other indicators. Gonads containing degenerating ovarian tissue and developing testicular tissue suggest sex change and therefore are important indicators of protogyny.

Hastings (1981) mentioned that there are at least three types of sexual reversion, depending on the stages of gonadal development. Webb \& Kingsford (1992) described three phases of sexual transition related to the different gonadal components and the proportions of the sexual cells.

In Northeast Brazil, between the States of Ceará and Alagoas, $M$. bonaci is caught by artisanal fishery using hook and line or compressor-assisted spear fishing. In 1998, they represented about 7,94\% total weight of the demersal fishes exploited commercially (IBAMA, 1999a, 1999b).

Fishing peaks occurs during a phenomenon known among local fishermen as the "correção" - which is an aggregation of these fish along the shelf break Northeastern coast during some periods of the year. The occurrence of this aggregation may be linked to the reproductive phase. As fishing pressure increases dramatically during these periods the overfishing may possibly affect the reproductive dynamics.

The largest suspicion of Serranids' vulnerability to fishing is based on the premise that overfishing affects the largest and 
oldest males. This may result in low rates of fertilisation of the eggs produced by the population (Shapiro, 1984), in account of the combination of insufficient sperm and social disruption.

This study describes the reproductive biology of $M$. bonaci in Northeast Brazil in terms of reproductive mode, gonadal development, spawning mode and seasonality, and evaluates the phenomenon called "correção".

\section{Material and Methods}

Study area. The area studied was made up of the outer continental shelf (bellow 40 meters), shelf break and oceanic banks, between the States of Ceará and Alagoas (Fig. 1).

In Cabo de São Roque, in the State of Rio Grande do Norte, the Northern section of the shelf presents different morphologic and oceanographic characteristics from the Southern section.

The outer edge shelf is outlined by a narrow continental slope that presents a soft declivity in the Northern part of Cabo de São Roque and a sharp declivity in the Southern part (Mabesoone \& Coutinho, 1970; Guazelli \& Carvalho, 1981). Oceanic banks such as Sirius, Guará and Aracati occur on the continental shelf and continental rise to the North of Cabo de São Roque (Guazelli \& Carvalho, 1981; Hazin, 1993).

The surface currents on the continental shelf are branches of the South Equatorial Current. A part of this current, called the Guyana Current, goes northward and crosses the Equator; the remaining current goes southward, along the South American continent and is called the Brazil Current (Pickard \& Emery, 1990).

Due to these morphologic and oceanographic differences it was determined that fish caught between the State of Ceará and Cabo de São Roque are considered as being from the North area and fish caught between the Cabo de São Roque and the State of Alagoas are from the South area (Fig.1).

Sampling. Fishes were sampled monthly in the most important localities of fishing landing (Caiçara do Norte, Tamandaré and São José da Coroa Grande), between August 1996 and April 1998, and 492 individuals of M. bonaci were collected. Data was also obtained within the Brazilian Economic Exclusive Zone Study Program (REVIZEE Program) through research expeditions, carried out on board the ship R/V Martins Filho, property of the Federal University of Ceará. Samples were obtained using longliners, on the continental slope and on the reef banks, between Ceará and the North of Alagoas.

The monthly production of the black grouper for the states of Rio Grande do Norte and Pernambuco, between 1993 and 2001, was obtained from the Northeast Fisheries Statistics Bulletin of the Brazilian Environmental Institute (IBAMA, 1994a, 1994b, 1995a, 1995b, 1996a, 1996b, 1997a, 1997b, 1998a, 1998b, 1999a, 1999b, 2000, 2001, 2002).

Total length $\left(L_{\mathrm{T}}\right)$, fork length $\left(L_{\mathrm{F}}\right)$ and standard length $\left(L_{\mathrm{S}}\right)$ of the fishes were measured in centimeters; total weight $\left(W_{\mathrm{T}}\right)$ and gutted weight $\left(W_{\mathrm{Gu}}\right)$ were measured in kilograms.

Gonads from 50 individuals collected between February
1997 and January 1998 were preserved in F.A.A.C.C. (formaldehyde $4 \%$, acetic acid $5 \%$, calcium chloride $1,3 \%$; Ferreira, 1993a). Histological description of the gonads and stages of maturity were obtained using the middle part of the gonads sampled, which had been previously determined as similar at the stage among the three parts of the gonads. The gonads were embedded in paraffin, sectioned transversally at $4 \mu \mathrm{m}$ and stained with haematoxylin-eosin and Gommory's trichromic (Beçak \& Paulete, 1976).

Stages of oogenesis and spermatogenesis were adapted from Nagahama (1983), Ferreira (1995) and García-Diaz et al. (1997). The definition of sexual transition followed the description of Hastings (1981) and the transition's stage followed those of Webb \& Kingsford (1992).

The spawning mode was determined by analyzing the frequency of the oocytes' diameters and the mode of the development of the oocytes. For the frequency analysis of the oocytes' diameters, two preserved gonads of the anterior, medium and posterior part of mature females were placed in modified Gilson's solution (Vazoller, 1996) and preserved in alcohol $70^{\circ}$.

The spawning season was determined through the temporal variation of the frequency of the gonadal stages, from histological analyses and by the temporal variation of the gonadosomatic index (GSI) (García-Diaz et al., 1997).

GSI was calculated as: $G S I=\left(W_{\mathrm{Go}} \times 100\right) / W_{\mathrm{Gu}}$, where the $W_{\mathrm{Go}}=$ gonadal total weight $(\mathrm{g})$, and $W_{\mathrm{Gu}}$ = gutted weight $(\mathrm{g})$.

Thirteen fishes caught no gutted during the "correção" were examined. The relative amount of fat deposited in the mesenteries was observed and determined by the number of parts of the viscera covered by fat in a discrete scale from 0 to 10. Results were presented as percentage (i.e., 5 fat parts in 10 viscera parts were equal at $50 \%$, etc).

Interviews, conducted with forty fishermen from Caiçara do Norte, Tamandaré, São José da Coroa Grande and Paripueira, included questions about time and periodicity and aspects of fishing and reproduction during the "correção".

Data analysis. The structure analysis of the size of the catch size was carried out using distributions of frequency of fork length. In every analysis, normality was tested using the Kolmogorov-Smirnov test and the supposition of homoscedasticity was tested through the plot of the regression's residues.

Kolmogorov-Smirnov tests were used, whenever the distribution levels were not normal, in order to test the difference between the frequency distributions of fish caught in the Northern section and in the Southern section of the study area (Crimp, 1987; Zar, 1996).

All statistical tests were made at the significance level of $\mathrm{P}=0.05$.

\section{Results}

Structure of the catch size. The structural size of the fish caught were analysed through the frequency distribution of the fork lengths for all fish (Fig. 2) and from the North (Fig. 3) and South (Fig. 4) areas. 
In the South area fish size was normally distributed $(\mathrm{P}>$ $0.05, \mathrm{KS})$ with modes in the lengths 90 and $95 \mathrm{~cm}$. However, the distributions in the north area and for both areas together did not meet a normal distribution $(\mathrm{P}<0.05, \mathrm{KS})$. The distribution mode for the North area was $70 \mathrm{~cm}$ and for the areas pooled were $70 \mathrm{~cm}$ and $75 \mathrm{~cm}$ of fork length.

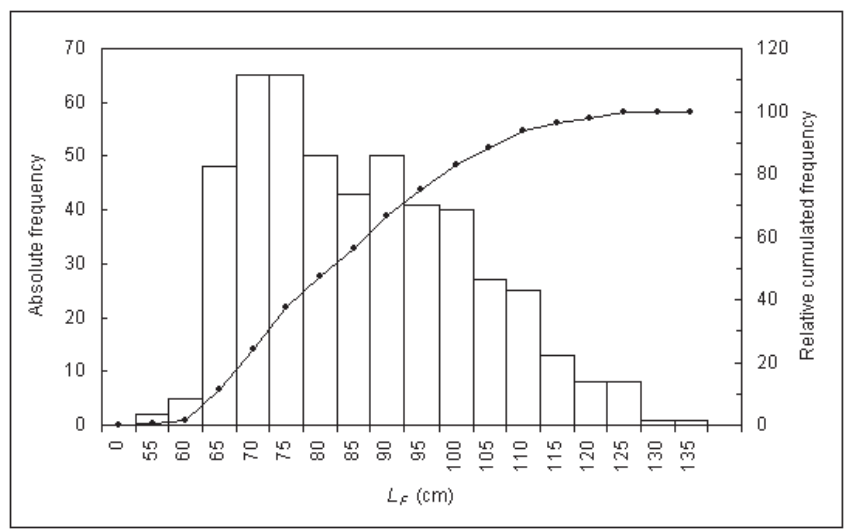

Fig. 2. Size distribution of absolute frequency (columns) and relative cumulated frequency (line) for total sampled of black grouper Mycteroperca bonaci.

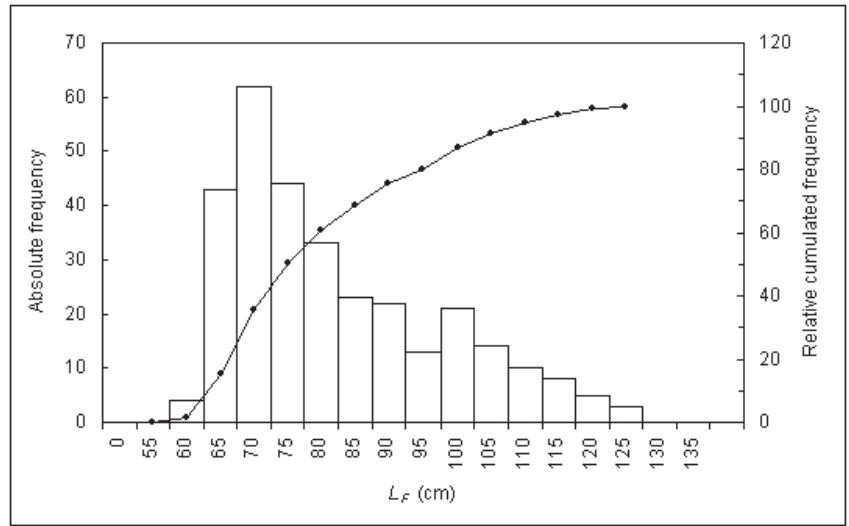

Fig. 3. Size distribution of absolute frequency (columns) and relative cumulated frequency (line) for black grouper Mycteroperca bonaci caught in North area.

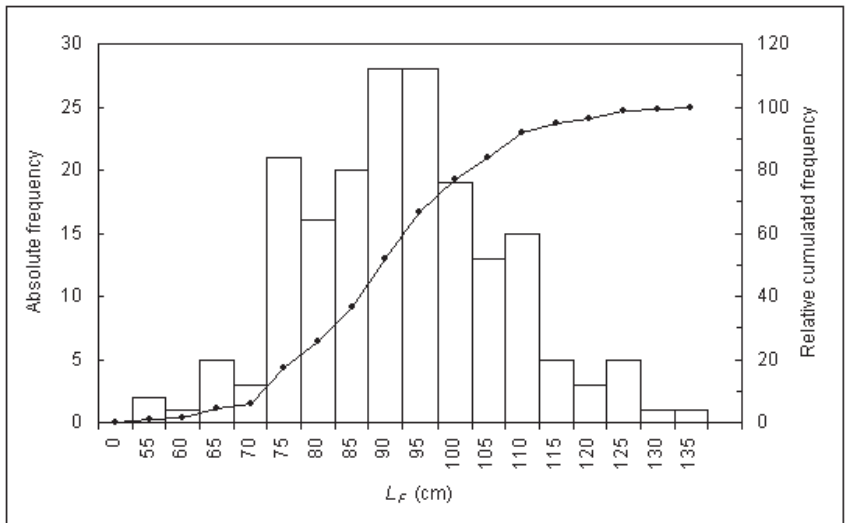

Fig. 4. Size distribution of absolute frequency (columns) and relative cumulated frequency (line) for black grouper Mycteroperca bonaci caught in South area.
A significant difference was detected between the North and South areas $(\mathrm{P}<0.05, \mathrm{KS})$.

Oocyte development. The ovarian lamellae possess, in their ovarian stroma, germinative cells at different oocyte development stages, according to the stage of gonadal maturity.

The germinative cells or oocytes develop gradually inside the ovary. The oocytes go through different stages of previtellogenic and vitellogenic growth (Table 1), until they complete their maturation and are released.

Gonadal stages. The gonadal stage was determined according to the most advanced oocyte stage and the aspect of the gonadal wall and ovarian lamellae. Six stages were observed: four for the females, one for the males and another transitional stage. Table 2 shows the number of individuals by gonadal stage and the ranges of the individuals' fork length.

Table 1. Oocyte stages of the black grouper Mycteroperca bonaci.

\begin{tabular}{|c|c|}
\hline & Pre-Vitellogenic Growth \\
\hline Gonium stage & $\begin{array}{l}\text { Small cells ranging between } 0.008 \text { and } 0.018 \mathrm{~mm} \text {, } \\
\text { which are round and/or oval. Cytoplasm is slightly } \\
\text { basophilic. Large nucleus, with more color than } \\
\text { the cytoplasm, with prominent nucleolus, in a } \\
\text { central position. A thick layer of follicular cells } \\
\text { surrounds the gonium. }\end{array}$ \\
\hline $\begin{array}{l}\text { Chromatin } \\
\text { Nucleolus Stage }\end{array}$ & $\begin{array}{l}\text { Round and/or oval cells. Most are larger in size } \\
\text { than the one in the gonium ( } 0.010 \text { to } 0.032 \mathrm{~mm}) \text {. } \\
\text { Basophilic cytoplasm, with slightly more color } \\
\text { than during previous stage. The nucleus at } \\
\text { peripheral position - which has } 1 \text { or } 2 \text { conspicuous } \\
\text { round nucleoli - is intensely basophilic. When the } \\
\text { nucleus possesses only one nucleoli, it occupies } \\
1 / 3 \text { of the nucleus. }\end{array}$ \\
\hline $\begin{array}{l}\text { Early } \\
\text { Perinucleolus } \\
\text { Stage }\end{array}$ & $\begin{array}{l}\text { Cells measuring between } 0.020 \text { and } 0.070 \mathrm{~mm} \text {, with } \\
\text { several forms - round, oval, triangular or rectangular. } \\
\text { The cytoplasm is intensely basophilic with an } \\
\text { affinity for Hematoxylin. Nucleus with } 1 \text { to } 3 \\
\text { nucleoli, initially, increasing in number and migrating } \\
\text { to the periphery. In this stage, the presence of } \\
\text { lampbrush chromosomes is observed in the nucleus. }\end{array}$ \\
\hline $\begin{array}{l}\text { Late } \\
\text { Perinucleolus } \\
\text { Stage }\end{array}$ & $\begin{array}{l}\text { Round and/or rectangular oocytes measuring of } \\
0.070 \text { to } 0.210 \mathrm{~mm} \text {. The cytoplasm becomes less } \\
\text { basophilic. Formation of small vesicles takes place } \\
\text { in the cytoplasm. The presence of an acidophilus } \\
\text { continuous membrane is observed around the cell, } \\
\text { which will constitute the yolk membrane. }\end{array}$ \\
\hline \multicolumn{2}{|r|}{ Vitellogenic Growth } \\
\hline $\begin{array}{l}\text { Cortical Vesicle } \\
\text { Stage }\end{array}$ & $\begin{array}{l}\text { Oocyte measuring between } 0.095 \text { to } 0.240 \mathrm{~mm} \text {. } \\
\text { Emergence of some yolk globule from the cortical } \\
\text { cytoplasm. Irregular nucleus with small, numerous } \\
\text { nucleoli in its periphery. The yolk membrane } \\
\text { becomes thicker. The layer of follicular cells } \\
\text { becomes more visible with a single layer of flat } \\
\text { cells and a central nucleus. }\end{array}$ \\
\hline $\begin{array}{l}\text { Early Yolk } \\
\text { Globule Stage }\end{array}$ & $\begin{array}{l}\text { Oocytes measuring between } 0.220 \text { and } 0.240 \mathrm{~mm} \text {. } \\
\text { Yolk globule increase in number and size due to } \\
\text { fusion and are located in the medium portion of } \\
\text { the cytoplasm. }\end{array}$ \\
\hline $\begin{array}{l}\text { Late Yolk } \\
\text { Globule Stage }\end{array}$ & $\begin{array}{l}\text { Oocyte measuring between } 0.400 \text { and } 0.720 \mathrm{~mm} \text {. } \\
\text { Numerous yolk globules dispersed in the } \\
\text { cytoplasm. The yolk membrane reaches its } \\
\text { maximum thickness. }\end{array}$ \\
\hline
\end{tabular}


Table 2. Number of fishes (n) and range of fork length $\left(L_{\mathrm{F}}\right)$, in centimeters, for gonadal stages.

\begin{tabular}{lcc}
\hline Gonadal Stages & $\mathrm{n}$ & $L_{\mathrm{F}}(\mathrm{cm})$ \\
\hline Female & 2 & $67.4-114.0$ \\
Early Maturation & 2 & $92.5-94.0$ \\
Ripe & 3 & $72.0-86.5$ \\
Spent & 33 & $58.0-123.0$ \\
Resting & 8 & $64.0-85.5$ \\
Transitional & & \\
Male & 2 & $109.5-118.0$ \\
$\quad$ Ripe &
\end{tabular}

\section{Females}

- Early Maturation: thin gonadal wall and very organized ovarian lamellae. In the ovarian stroma, several oogonia and oocytes from the chromatin nucleolus stage to the late perinucleolus stage are found (Fig. 5).

- Ripe: the ovaries have a thin gonadal wall. The ovarian stroma is filled with oocytes at chromatin-nucleolus stage and at perinucleolus stage. The oocytes at all vitellogenic stages dominated, mainly those in the late yolk globule stage (Fig. 6). Some oocytes in the late yolk globule stage are found in re-absorption.

- Spent: the gonadal wall is thick. The ovarian lamella is disorganized. In the ovarian stroma oocytes undergo atresia and there are post-ovulatory follicles, oocytes in previtellogenic growth (chromatin nucleolus to the late perinucleolus stages) and vitellogenic growth (Fig. 7).

- Resting: thin gonadal wall and organized ovarian lamellae (Fig. 8). Many oogonia, at the periphery of the ovarian lamellae; oocytes in the chromatin nucleolus stage and early perinucleolus stage are observed in the ovarian stroma.

\section{Transitional}

Gonads undergoing sex change, consisting of crypts of dispersed spermatids, were found among degenerating vitellogenic oocytes (Figs. 9-10). A total of eight transitional gonads were examined.

\section{Males}

- Ripe: all stages of spermatogenesis and spermiogenesis presents (Fig. 11). Also present in all males was vestigial non-functional lumen and remnant oocytes (Fig. 12).

During the phenomenon of the "correção", corresponding to the period of aggregation of $M$. bonaci, the gonads were in the resting $(\mathrm{n}=28)$ and transitional $(\mathrm{n}=7)$ stages. All fish had more than $50 \%$ fat, half of these fish contained more than $70 \%$ of fat (Fig. 13).

Spawning mode. The presence of oocytes in several phases of pre-vitellogenic and vitellogenic development indicated asynchronous oocyte development, typical of fish with multiple spawning.

This phenomenon was also observed during the analysis of the frequency of the oocytes' diameter of two ripe females, where oocytes of all sizes, from 0.080 to $0.720 \mathrm{~mm}$, were found (Fig. 14a-b).
Spawning season. Early maturation females were collected during February/March and April/May and ripe females during April/May and August/September. Spent females happened in August/September and October/November; and, resting females happened in February/March, April/May and December/January (Fig. 15).

The gonadosomatic index (GSI) is shown in Figure 16. The highest GSI is found in August/September.

Histological results and the gonadosomatic index suggest that the spawning season occurs between April and September.

"Correção". The interviews were carried out individually. Fishermen were selected based on their experience, that ranged from a period between 20 and 45 years in Caiçara do Norte $(n=10) ; 10$ and 41 years in Recife $(n=10) ; 10$ and 40 years in São José da Coroa Grande $(\mathrm{n}=10)$; and, 11 and 47 years in Paripueira $(n=10)$. All the fishermen interviewed had already fished during the "correção" at least twice.

When asked about how the "correção" starts, $80 \%$ answered that the black grouper comes to feed from the depths running by

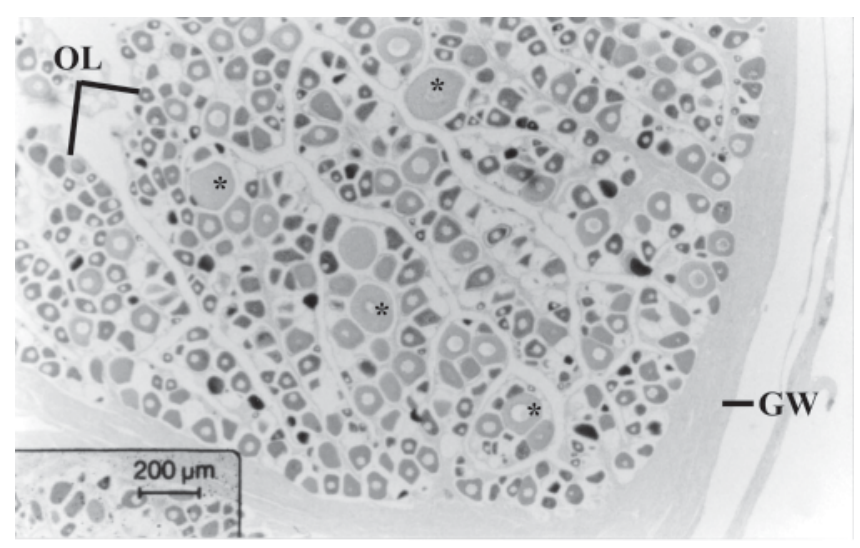

Fig. 5. Transverse section of an early maturation ovary of Mycteroperca bonaci. Gonadal wall (GW), ovarian lamellae (OL), and oocytes in the late perinucleolus stage (*). Stain: H.E.

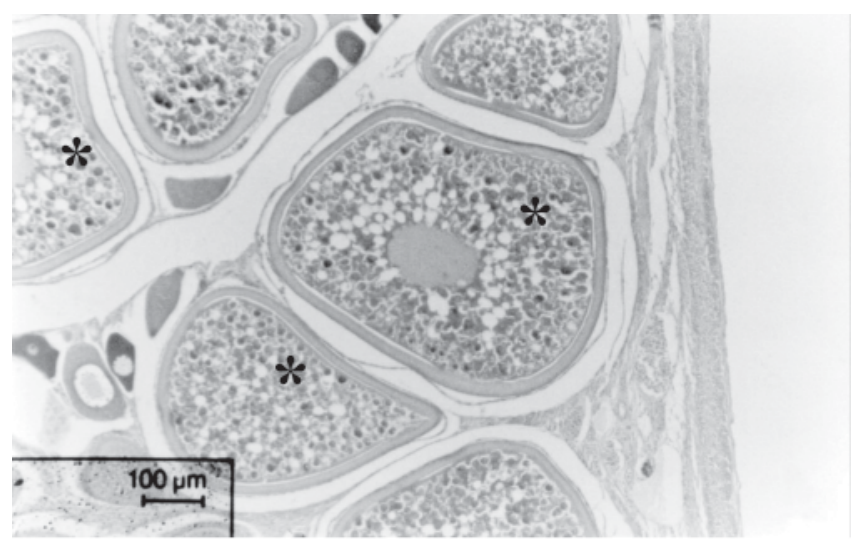

Fig. 6. Transverse section of a ripe ovary of Mycteroperca bonaci showing great amount of oocytes in the final phases of vitellogenic growth (*). Stain: H. E. 
the "walls" (shelf break). The phenomenon was called "correção" after these observations. The other $20 \%$ did not find any reason for this, but all said that the fish show signs of starvation because they attack the bait with great voracity.

When asked about the progression of this "run" all answered that the "correção" begins up North, in the State of Ceará, and proceed southward, ending in Bahia, where this phenomenon is known as "arribada".

In relation to the periodicity and the time of the "correção", according to the majority of the interviewees, it occurs every year, between October and January, in Caiçara do Norte; every four to five years, between October and January, in Recife; every three years, between January and March, in São José da Coroa Grande and every three to four years, between January and February, in Paripueira (Figs. 17-18).

The Northeast Fisheries Statistics Bulletin of IBAMA (1994a, 1994b, 1995a, 1995b, 1996a, 1996b, 1997a, 1997b, 1998a, 1998b, 1999a, 1999b, 2000, 2001, 2002) reported for the states of Rio Grande do Norte and Pernambuco a marked increase in the black grouper landings at the same period of the "correção" reported by the fishermen (Fig. 19).

When asked whether other species were also caught during the "correção", the fishermen of Caiçara do Norte

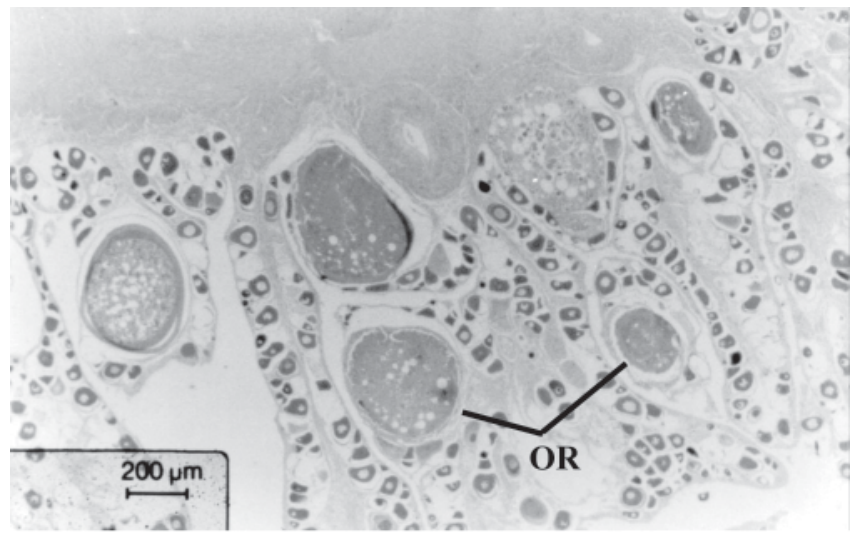

Fig. 7. Transverse section of a spent ovary of Mycteroperca bonaci showing oocytes in reabsorption (OR). Stain: H. E.

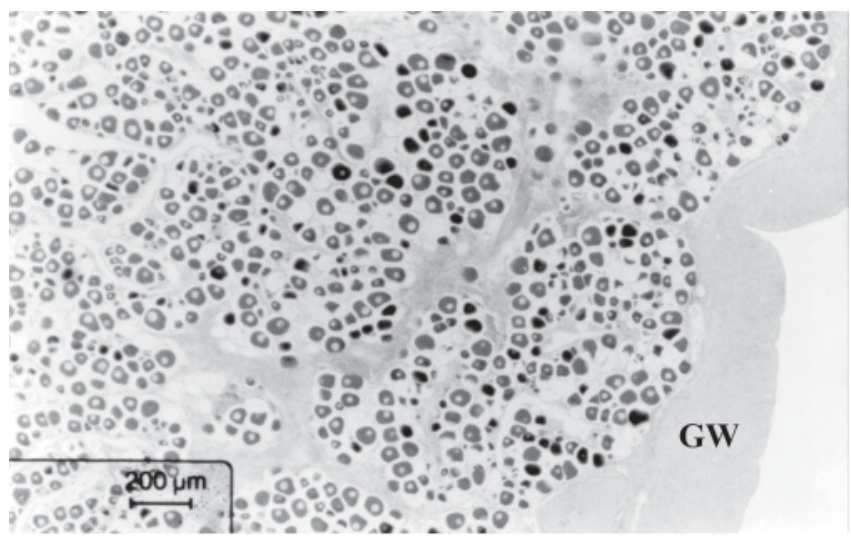

Fig. 8. Transverse section of a resting ovary of Mycteroperca bonaci. Gonadal wall (GW). Stain: H. E. informed that the most commonly caught species were the mutton snapper (Lutjanus analis), dog snapper (Lutjanus jocu) and once, the yellowtailed snapper (Lutjanus chrysurus).

A very interesting fact that every fisherman pointed out is that a sequence exists in the "correção". The first species expected during the "correção" is the mutton snapper, followed by two species, which are often together, the dog snapper and the black grouper. Thus, the mutton snapper "correção", in Caiçara do Norte, serves as an indicator that the "correção" of the black grouper is close.

The "correção" in Recife occurs with the black grouper, dog snapper, mutton snapper and almaco jack/greater amberjack (Seriola spp), and, occasionally, the yellowtailed snapper. In São José da Coroa Grande and Paripueira, the "correção" also happens with the black grouper, dog snapper, mutton snapper and almaco jack/greater amberjack at the same time.

The fishing of the black grouper during the "correção" only happens near the "walls" - the area of shelf break - from dawn until the evening. During the "correção" the black

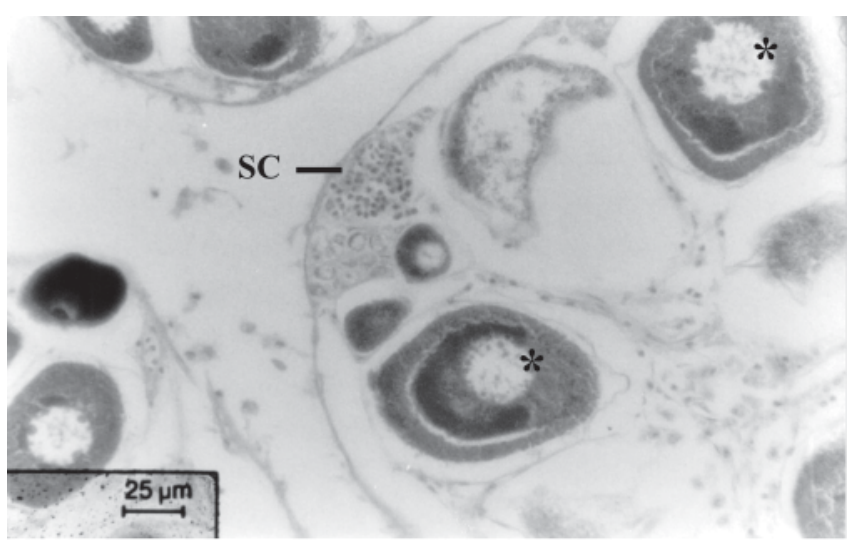

Fig. 9. Development of spermatid crypts (SC) in the estroma of Mycteroperca bonaci in transition period. Presence of countless oocytes with their nucleus erode and the fragmented cytoplasm (*). Stain: H. E.

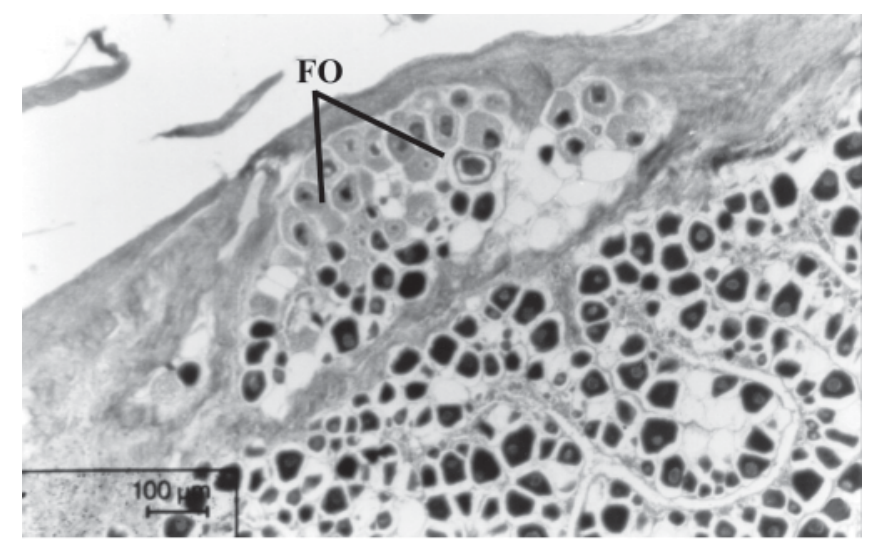

Fig. 10. Transverse section of the gonad of Mycteroperca bonaci showing oocytes with eroded nucleus and cytoplasm fragmented in transitional individual. Fragmented oocytes (FO). Stain: Gommory. 
grouper will gorge on any bait, but with a special preference for Selar crumenophthalmus, Chloroscombrus chrysurus, Hirundichthys spp, Cypselurus and Thunnus sp.

When questioned on the appearance of the gonad and viscera of the black grouper, caught during the "correção", $91.30 \%$ of all the fishermen said that "fish had fat and no gonads'. This means that fishes have reduced gonad, which is characteristic of the stages out of maturation period, and that they also had a fat layer covering its viscera.

Every interviewee from Caiçara do Norte noticed that catches during the "correção" had dropped over the last few years. In Recife, $90 \%$ said that catches had decreased, while $10 \%$ could not answer. In São José da Coroa Grande, 90\% reported reduced catches and $10 \%$ had no opinion. In Paripueira, $70 \%$ reported extremely reduced catches, $20 \%$ said they varied and $10 \%$ said they had weakened. Two fishermen from Recife with 22 and 30 years of fishing experience, a fisherman from São José da Coroa Grande with 26 years experience and another one from Paripueira with 41 years of

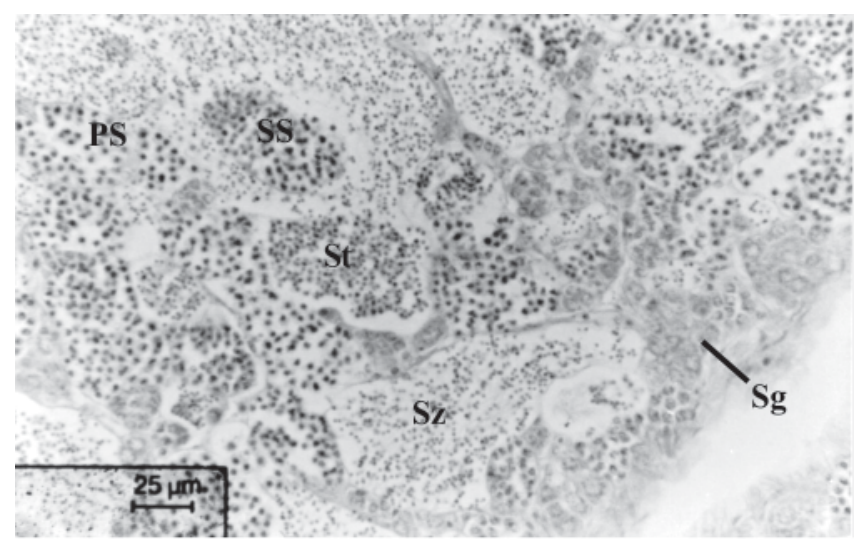

Fig. 11. Transverse section of the testicle of Mycteroperca bonaci showing the different development stages: spermatogonia (Sg), primary spermatocytes (PS), secondary spermatocytes (SS), spermatides (St) and spermatozoa (Sz). Stain: H. E.

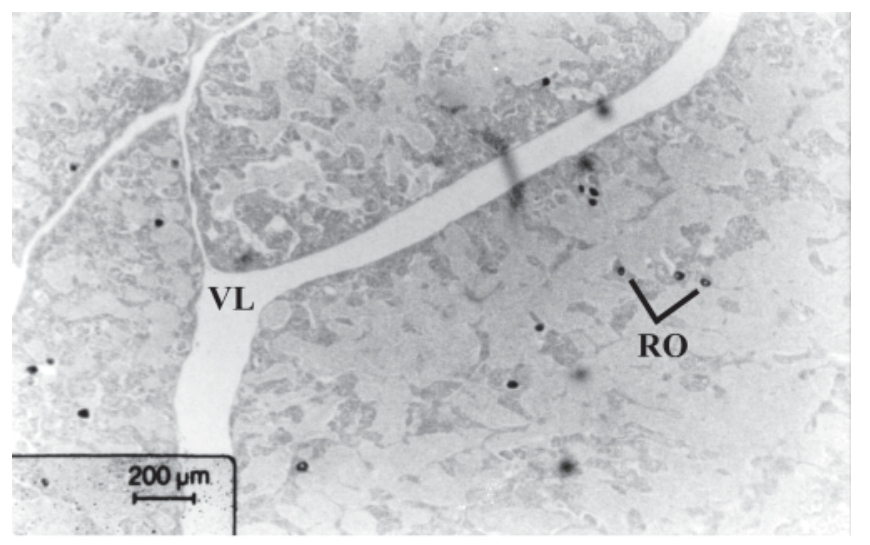

Fig. 12. Transverse section of the testicle of Mycteroperca bonaci showing the vestigial lumen (VL) and remaining oocytes (RO) in its interior. Stain: H. E. fishing experience have said, spontaneously, that the catch related to the "correção" had been reduced due to the increase of the fishing effort in the last few years. In Recife, a fisherman that has been working in the fishing sector for 41 years also

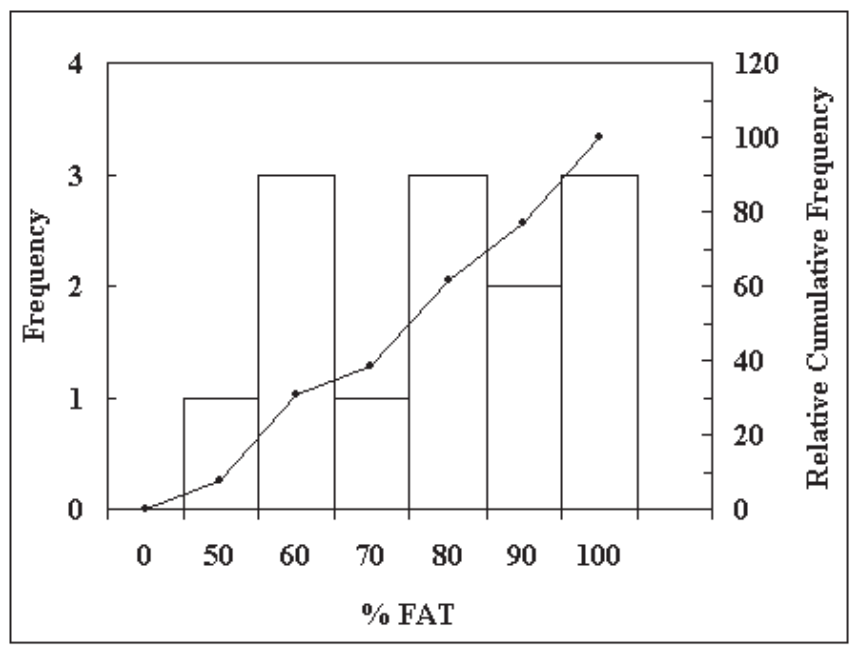

Fig. 13. Distribution of absolute frequency (columns) and relative cumulated frequency (line) of the percentile of fat in the body cavity of Mycteroperca bonaci during the "correção".

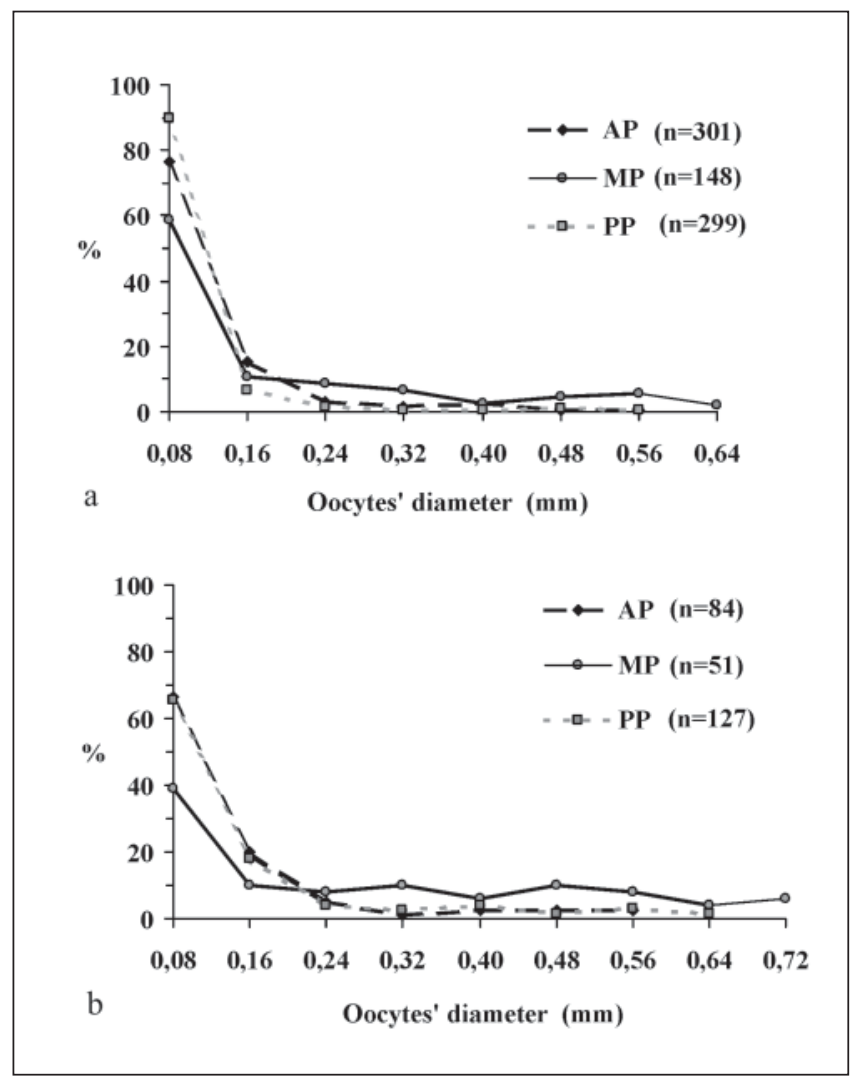

Fig. 14a-b - Distribution of the relative frequency of the oocytes' diameter of the anterior (AP), medium (MP) and posterior (PP) portions of gonads of two ripe females of Mycteroperca bonaci. 


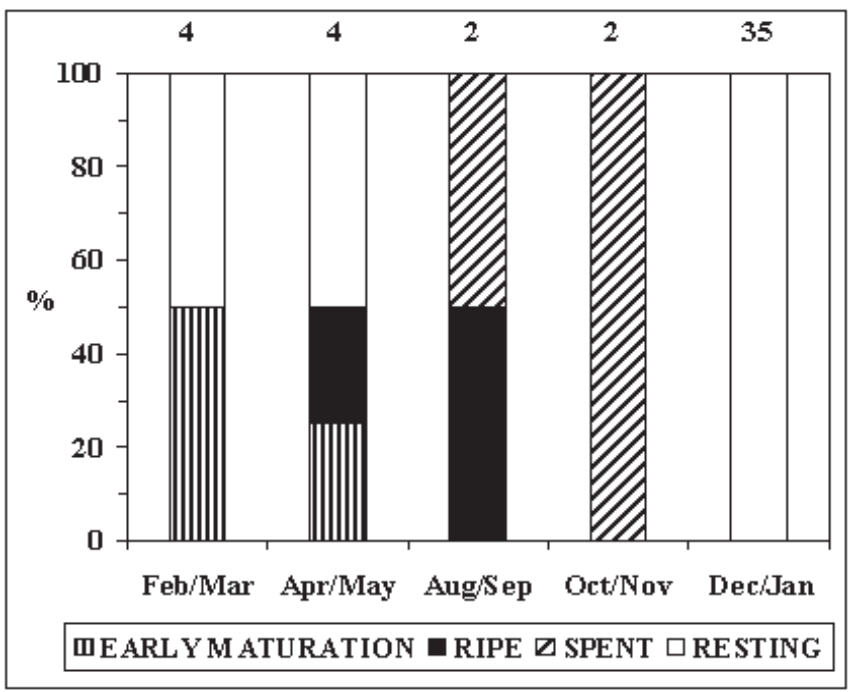

Fig. 15. Relative frequency of the stages of maturity of the females of Mycteroperca bonaci.

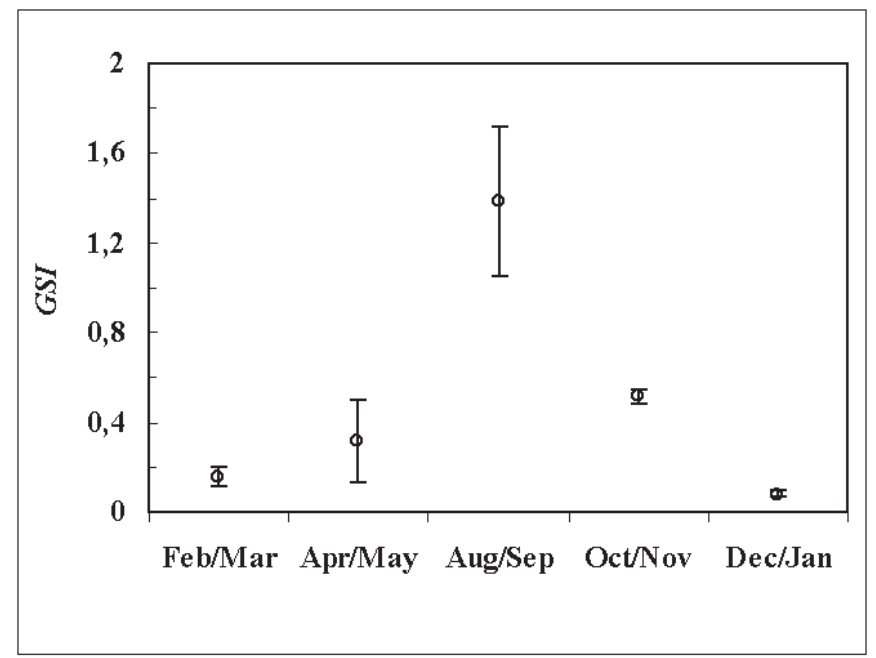

Fig. 16. Variation of the gonadosomatic index (GSI) for females of Mycteroperca bonaci. Bar indicates standard deviation values.

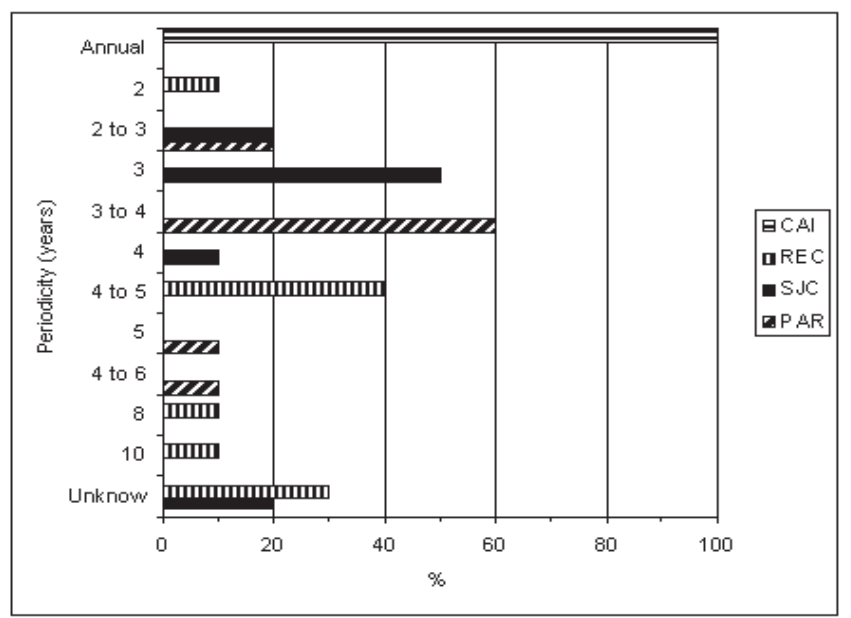

Fig. 17. Periodicity of the "correção" in Caiçara do Norte (CAI), Recife (REC), São José da Coroa Grande (SJC) and Paripueira (PAR) according to the interviewees. added that the catch of the black grouper using a hook and line has decreased due increase effort using compressorassisted spear fishing.

\section{Discussion}

Fishery of Mycteroperca bonaci in the North as much as in the South of the study area shows similarities. These are: the catch depth (between 50 and 120 meters), the vessel types (small and medium motorised vessels) and the fishing equipment used (hook and line and compressor-assisted spear fishing). On the Northern fishing ground, fishing activity occurs near the shelf break and on oceanic banks, whereas on the Southern fishing ground it only occurs in the shelf break. Furthermore, the number of vessels that work in the Northern area is, approximately, four times larger than the Southern area. This fact is backed up by the total catch of the black grouper: the Northern area produces more than the South (IBAMA, 1994a, 1994b, 1995a, 1995b, 1996a, 1996b, 1997a, 1997b, 1998a, 1998b, 1999a, 1999b, 2000, 2001, 2002). This indicates that in the Northern area the species may already be overfished.

Higher fishing levels in the North area may have lead to a reduction of the individuals' size, since fishing with a hook and line and compressor-assisted spear fishing are size selective, and therefore remove the largest individuals from the population (Ricker, 1969).

Differences of length frequency distributions may also be related to the declivity of the outer shelf break, which is less abrupt in the North area than in the South. Serranids, for instance, the Mycteroperca microlepis, show stratification size, with young individuals being distributed in shallow sites like estuaries, seagrass beds and shallow reefs, and adults in deep reefs (over 50 meters deep) (Koenig \& Coleman, 1998). Therefore, as the declivity in the North area is less abrupt and shows stratification size, larger individuals are possibly less vulnerable to fishing. This may explain why smaller individuals are caught in the North area.

Another possibility is that the observed differences are due to isolation of populations on account of the divergence of the Equatorial South Current, in the Currents of Guyana and the Current of Brazil, close to Cabo de São Roque (Pickard $\&$ Emery, 1990). The conditions of dispersion of the eggs and larvae of reef fishes may not allow genetic isolation as the superficial currents are vectors of genetic flows of marine species with larval dispersion (Roberts, 1997). However, this hypothesis needs to be verified and should be part of future research.

Anatomical and histological analyses, revealed that the gonad of M. bonaci presents the Epinephelus type mentioned by Smith (1965) and its morphology is similar to that described for other serranids (Bortone, 1977; García-Cagide \& García, 1996; Sadovy \& Colin, 1995).

The oocyte development stages of Mycteroperca bonaci are similar to most marine teleosts (Nagahama, 1983; Ebisawa, 1990; Davis \& West, 1993; Ferreira, 1995; García-Diaz et al., 
1997). The only oocyte type not observed was the hydrated oocyte. Probably due to the reduced number of ripe females sampled, and to the fact that hydration is the most ephemeral stage of all (Hunter \& Macewicz, 1985). Thus, being the hydrated oocyte rarely visible (Goeden, 1978), favorable conditions and a satisfactory sampling number are required.

The absence of immature females is probably related to fishing characteristics such as fishing ground and equipment selectivity. The smallest sizes are not vulnerable to these fishing gears and were not available for sampling. According to García-Cagide \& García (1996), the size of first maturation of $M$. bonaci is between 50 and 60 centimeters total length, but sampled gonads were from individuals larger than 61 centimeters total length.

According to Sadovy \& Shapiro (1987), the most evident of the ten indicators of protogynous hermaphroditism is the transitional individuals' presence.

Hastings (1981) mentions three forms of re-absorption of the ovarian tissue, together with proliferation of the testicular tissue that indicate gonadal transformation from female to male. Firstly, un-ovulated mature ova become encysted with fibroblasts and invaded by cells of unknown origin; secondly,
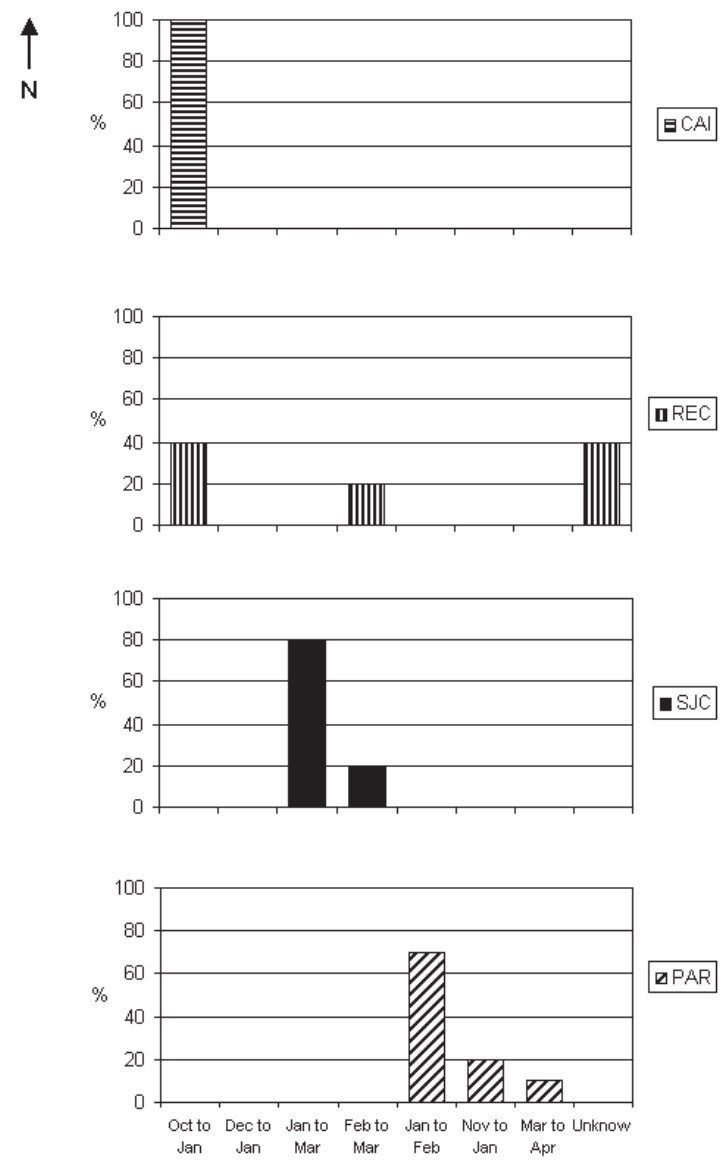

Fig. 18. Time of the "correção" in Caiçara do Norte (CAI), Recife (REC), São José da Coroa Grande (SJC) and Paripueira (PAR) according to the interviewees (arrow indicates the north direction). vitellogenic oocytes are invaded and phagocytised by the cells of the granular layer; and, thirdly, no vitellogenic oocytes are fragmented.

According to Webb \& Kingsford (1992), this transformation occurs gradually and varies with the proportion of testicular tissue and the presence of remnant oocyte in gonad. This transformation may be divided into three stages: initial, medium and final.

A form of re-absorption of the ovarian tissue was found in seven characteristic gonads of the resting stage and in another one of the early maturation stage. This form presented proliferation of spermatid crypts, as mentioned in Hastings (1981), and, in agreement with Webb \& Kingsford (1992), was in the initial stage of sex transformation. Crabtree \& Bullock (1998) presented as evidence of protogynous hermaphroditism for $M$. bonaci in Florida, the presence of a vestigial lumen in male gonads, vitellogenic oocytes in degeneration in the transitional gonads and the absence of small or young males. These evidences were also found for $M$. bonaci in Brazil, confirming that this species is a protogynous hermaphrodite. García-Cagide \& García (1996) also pointed out this same hermaphroditism type for $M$. bonaci of Cuba.
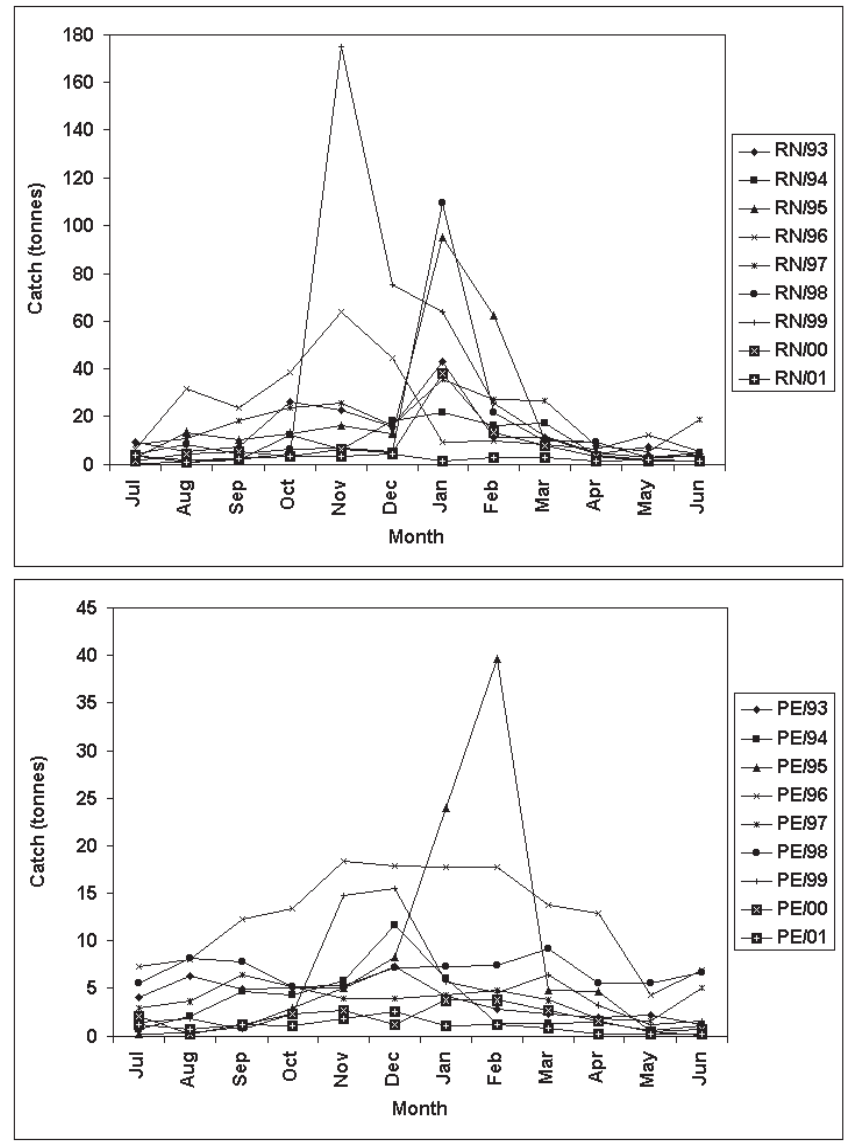

Fig. 19. Monthly catch of the Mycteroperca bonaci for the states of Rio Grande do Norte (North area) and Pernambuco (South Area) from Northeast Fisheries Statistics Bulletin (IBAMA). RN: Rio Grande do Norte/year, PE: Pernambuco/year. 
The smallest size of $M$. bonaci in transition was $64 \mathrm{~cm}$ $\left(L_{F}\right)$. This size is similar to the size of the Cuban M. bonaci $\left(L_{T}\right.$ of $65 \mathrm{~cm}$ ) determined by García-Cagide \& García (1996), but smaller than the Floridian type observed by Crabtree \& Bullock (1998) with a $L_{T}$ of $94,7 \mathrm{~cm}\left(92,3 \mathrm{~cm} L_{F}\right)$. This may suggest that the black grouper stocks in the northeast of Brazil are overexploited and that this has lead to sex change at a smaller size in order to guarantee their survival. The smallest size also suggests that social control exists on the sexual reversion and that $M$. bonaci is probably not exclusively size or age dependent to sex change.

The multiple spawning mode found in M. bonaci was also observed on the Cuban shelf (García-Cagide \& García, 1996). The reproduction of the serranids studied so far, as Epinephelus guttatus (Sadovy, Rosário \& Román, 1994), Epinephelus striatus (Smith, 1972), Mycteroperca venenosa (García-Cagide \& García, 1996), Plectropomus leopardus (Ferreira, 1995), Plectropomus maculatus (Ferreira, 1993b) and, Serranus cabrila (García-Diaz et al., 1997) show the same spawning mode.

The bimonthly maturity stage frequency, obtained by the observation of early maturation, ripe and spent females and of the gonadosomatic index, indicated that spawning probably occurs from April to September. The spawning season of the Cuban $M$. bonaci is from November to May with peaks recorded in November and February (García-Cagide \& García, 1996). In Florida, Crabtree \& Bullock (1998) indicate that the peak of spawning of $M$. bonaci is from December to March.

Ethnobiology studies based on interviews and direct observations are bringing a lot of contributions lately to the biological and behavioural knowledge of the species (Begossi \& Figueiredo, 1995). According to Johannes (1993), interviews that are based on questionnaires are advised to obtain information on pre-determined subjects. These interviews are defective when the interviewer does not have previous knowledge of a particular subject. To avoid any mistakes, the questionnaires about the "correção" were made after having previous knowledge of the phenomenon. Also, questions involving time and periodicity were not precisely defined in order to avoid inducing the interviewees to choose readymade answers.

The phenomenon of the "correção" undergone by Mycteroperca bonaci seems to be a chain reaction that begins in the North, in the State of Ceará, ending in the South, in the State of Bahia.

However, the "correção" presents a regular periodicity annually - in the North section of the study area. In the South section, the "correção" occurs in irregular years, between 2 and 5 years, and therefore differs from the North area.

This irregular occurrence of the "correção" seems to be the reason why the answers of the questionnaires varied much more in the South than in the North, which had more concise and larger unanimous answers.

The period of the "correção" - according to the interviews and the annual fishing reports from IBAMA (1994a, 1994b, 1995a, 1995b, 1996a, 1996b, 1997a, 1997b, 1998a, 1998b, 1999a, 1999b, 2000, 2001, 2002) - indicated that, in the North area, the "correção" is expected between October and January; and, in the South area, between December and March.

The observations, during the "correção", of the gonadal stages and the proportion of fat suggested that $M$. bonaci was not in reproductive activity. All of the sampled gonads were in the resting stage presenting a large proportion of fat in the body cavity. This fat is used in the processing of the gonadal products and presents an inverse relation with the gonadal weight, as mentioned by Ferreira (1993a) for some serranids and by Rajasilta (1992) for Clupea harengus membras.

The "correção", during the studied time, did not present any association with the phases of the moon.

Considering, that Mycteroperca bonaci did not present indications of reproductive activity during the "correção"; that fishes attack the bait with great voracity, as mentioned by every interviewed fisherman; and, that the period of the "correção" did not present a synchronisation with the lunar phases, it can be suggested that this phenomenon is a feeding aggregation.

Based on this assumption, it seems that the black grouper takes advantage of the reproductive aggregations of other species as an opportunity to feed. This can be observed during the "correção" of Mycteroperca bonaci, in Caiçara do Norte, where its capture was associated to reproductive aggregations of Lutjanus analis, Lutjanus jocu and Seriola spp and confirmed by the presence of ripe gonads in these species (personal observation in situ). Thus the black groupers during the "correção", coming from ever deeper and inaccessible sites to the fishing gears', are vulnerable to fishing pressure and are massively caught, as recorded during sampling at the "correção" period and on the annual fishing reports of IBAMA (1994a, 1994b, 1995a, 1995b, 1996a, 1996b, 1997a, 1997b, 1998a, 1998b, 1999a, 1999b, 2000, 2001, 2002).

If this hypothesis is true, it diverges completely from what happens with other Epinephelinaes as the Epinephelus guttatus (Colin, Shapiro \& Weiler, 1987; Shapiro, Sadovy \& McGehee, 1993; Sadovy, Rosário \& Román, 1994; Shapiro, Garcia-Moliner \& Sadovy, 1994); Epinephelus striatus (Colin, Shapiro \& Weiler, 1987; Colin, 1992); Mycteroperca microleps and Mycteroperca phenax (Coleman, Koenig \& Collins, 1996); and Plectropomus leopardus (Samoilys \& Squire, 1994) that form aggregations to reproduce during a period from one to two weeks, at determined locations, during the new and full lunar phases. So, they can be caught in large numbers when aggregate.

The suspicion of the Serranids vulnerability to fishing is based on the premise that there is overfishing of the largest and oldest males, leading to a less reproductive potential (Shapiro, 1984).

Bannerot, Fox \& Powers (1987) investigated the effects of the reproduction of protogynous hermaphrodite in yield per recruit models and stock yield. They concluded that the management of these populations undergoing high fishing mortality is uncertain.

The effects of overfishing, already observed in other serranids, may lead to an abrupt reduction of stock, as has happened with Epinephelus striatus in the Caribbean (Colin, 1992) and as has 
been observed for the Brazilian jewfish Epinephelus itajara (Ferreira \& Maida, 1995). Local authorities in Florida have already banished in a definitive manner jewfish fishing activities in order to prevent its extinction (Bullock et al., 1992).

According to the fishermen interviewed Mycteroperca bonaci is probably already undergoing overfishing effects, since the capture of the black grouper has decreased on these last two decades.

As Mycteroperca bonaci is a protogynous hermaphrodite and aggregates at specific periods of the year, when it is caught intensively along the Northeastern coast, special attention should be given to this species to avoid possible overfishing. Therefore, there is an urgent need for deeper studies on the biology population of the black grouper in order to develop an effective management plan.

\section{Acknowledgements}

We thank all the people who assisted in the fieldwork and to many commercial fishermen that allowed sampling of the black grouper during landing. This work was funded by grants from the Brazilian Ministry of Education (CNPq) and Brazilian Economic Exclusive Zone Programme - Score/NE.

\section{Literature Cited}

Bannerot, S., W. W. Fox Jr., \& J. E. Powers. 1987.Reproductive strategies and the management of snappers and groupers in the Gulf of Mexico and Caribbean. Pp. 561-603. In: Poots, G.W. \& R.J. Wooton (Eds.). Fish reproduction: strategies and tactics. Academic Press, Orlando.

Beçak, W. \& J. Paulete. 1976. Técnicas de Citologia e Histologia. Ed. Livros Técnicos e Científicos S. A., São Paulo, 305p.

Begossi, A. \& J. L. Figueiredo. 1995. Ethnoichthyology of southern coastal fishermen: cases from Búzios Island and Sepetiba Bay (Brazil). Bulletin of Marine Science, 56(2): 710-717.

Bortone, S. A. 1977. Gonad morphology of the hermaphroditic fish Diplectrum pacificum (Serranidae). Copeia, 3: 448-453.

Bullock, L. H., M. D. Murphy, M. F. Godcharles \& M. E. Mitchell. 1992. Age, growth and reproduction of jewfish Epinephelus itajara in the eastern Gulf of Mexico. Fishery Bulletin, 90: 243-249.

Coleman, F. C., C. C. Koenig \& L. A. Collins. 1996. Reproductive styles of shallow-water groupers (Pisces: Serranidae) in the eastern Gulf of Mexico and the consequences of fishing spawning aggregations. Environmental Biology of Fishes, 47: 129-141.

Colin, P. L., 1992. Reproduction of the Nassau grouper, Epinephelus striatus (Pisces: Serranidae) and its relationship to environmental conditions. Environmental Biology of Fishes, 34: 357-377.

Colin, P. L., D. Y. Shapiro \& D. Weiler. 1987. Aspects of the reproduction of two groupers, Epinephelus guttatus and E. striatus in the West Indies. Bulletin of Marine Science, 40(2): 220-230.
Crabtree, R. E. \& L. H. Bullock. 1998. Age, growth, and reproduction of black grouper, Mycteroperca bonaci, in Florida waters. Fishery Bulletin, 96: 735-753.

Crimp, O. N. 1987. The Applicability of the KolmogorovSmirnov Test in Analysis Coral Trout (Plectropomus leopardus) Size Frequency Data. Maritime Estate Management Branch, Queensland National Parks and Wildlife Service. 38 p.

Davis, T. L. O. \& G. J. West. 1993. Maturation, reproductive seasonality, fecundity, and spawning frequency in Lutjanus vittus (Quoy and Gaimard) from the North West shelf of Australia. Fishery Bulletin, 91: 224-236.

Ebisawa, A. 1990. Reproductive biology of Lethrinus nebulosus (Pisces: Lethrinidae) around the Okinawan Waters. Nippon Suisan Gakkaishi, 56(12): 1941-1954.

Ferreira, B. P. 1993a. Age, growth, reproduction and population biology of Plectropomus spp (Epinephelinae: Serranidae) on the Great Barrier Reef, Australia. Unpublished Ph.D. Dissertation, James Cook University of North Queensland, Towsville, 187 p.

Ferreira, B. P. 1993b. Reproduction of the inshore coral trout Plectropomus maculatus (Perciformes: Serranidae) from the Central Great Barrier Reef, Australia. Journal of Fish Biology, 42: 831-844.

Ferreira, B. P. 1995. Reproduction of the common coral trout Plectropomus leopardus (Serranidae: Epinephelinae) from the Central and Northern Great Barrier Reef, Australia. Bulletin of Marine Science, 56(2): 653-669.

Ferreira, B. P. \& M. Maida. 1995. Projeto mero: apresentação e resultados preliminares. Boletim Técnico Científico do CEPENE, 3(1): 201-210.

García-Cagide, A. \& T. García. 1996. Reproducción de Mycteroperca bonaci y Mycteroperca venenosa (Pisces: Serranidae) en la plataforma cubana. Revista de Biologia Tropical, 44(2): 771-780.

García-Díaz, M. M., V. M. Tuset, J. A. González \& J. Socorro. 1997. Sex and reproductive aspects in Serranus cabrila (Osteichthyes: Serranidae): macroscopic and histological approaches. Marine Biology, 127: 379-386.

Goeden, G. B. 1978. A monograph of the coral trout Plectropomus leopardus (Lacépède). Qld. Fish. Serv., Research Bulletin, 1: 1-42.

Guazelli, W. \& J. C. Carvalho. 1981. Estruturas da margem continental leste brasileira e das áreas oceânicas e continentais adjacentes. Pp. 117-143. In: Asmus, H. E. (Ed.). Estruturas e tectonismo da margem continental brasileira, e suas implicações nos processos sedimentares e na avaliação do potencial de recursos minerais. Petrobrás, Rio de Janeiro.

Hastings, P. A. 1981. Gonad morphology and sex succession in the protogynous hermaphrodite Hemanthias vivanus (Jordan and Swain). Journal of Fish Biology, 18: 443-454.

Hazin, F. H. V. 1993. Fisheries - oceanographical study of tunas, billfishes and sharks in the Southwestern Equatorial Atlantic Ocean. Unpublished Ph.D. Dissertation, Tokyo University of Fisheries, Tokyo, 286 p. 
Heemstra,P.C.\& J.E. Randall. 1993.FAOSpecies Catalogue: Groupers of the world (Family Serranidae, Subfamily Epinephelinae). Fao Fisheries Synopsis Roma: FAO, 125 (16), 382 p.

Hunter, J. R. \& B. Macewicz. 1985. Measurement of spawning frequency in multiple spawning fishes. Pp. 79-94. In: Lasker, R. (Ed.). An egg production method for estimating spawning biomass of pelagic fish: application to the Northern anchovy Engraulis mordax. NOAA Technical Report vol. 36.

Ibama. 1994a. Boletim estatístico da pesca marítima do estado do Rio Grande do Norte - 1993. Tamandaré: CEPENE.

Ibama. 1994b. Boletim estatístico da pesca marítima no estado de Pernambuco - 1993. Tamandaré: CEPENE.

Ibama. 1995a. Boletim estatístico da pesca marítima do estado do Rio Grande do Norte - 1994. Tamandaré: CEPENE.

Ibama. 1995b. Boletim estatístico da pesca marítima no estado de Pernambuco - 1994. Tamandaré: CEPENE.

Ibama. 1996a. Boletim estatístico da pesca marítima do estado do Rio Grande do Norte - 1995. Tamandaré: CEPENE.

Ibama. 1996b. Boletim estatístico da pesca marítima no estado de Pernambuco - 1995. Tamandaré: CEPENE.

Ibama. 1997a. Boletim estatístico da pesca marítima e estuarina do estado do Rio Grande do Norte - 1996. Tamandaré: CEPENE.

Ibama. 1997b. Boletim estatístico da pesca marítima e estuarina no estado de Pernambuco - 1996. Tamandaré: CEPENE.

Ibama. 1998a. Boletim estatístico da pesca marítima e estuarina do estado do Rio Grande do Norte - 1997. Tamandaré: CEPENE.

Ibama. 1998b. Boletim estatístico da pesca marítima e estuarina no estado de Pernambuco - 1997. Tamandaré: CEPENE.

Ibama. 1999a. Boletim estatístico da pesca marítima do estado do Rio Grande do Norte - 1998. Tamandaré: CEPENE.

Ibama. 1999b. Boletim estatístico da pesca marítima no estado de Pernambuco - 1998. Tamandaré: CEPENE.

Ibama-NE. 2000. Boletim estatístico da pesca marítima e estuarina do nordeste do Brasil - 1999. Tamandaré: CEPENE.

Ibama-NE. 2001. Boletim estatístico da pesca marítima e estuarina do nordeste do Brasil - 2000. Tamandaré: CEPENE.

Ibama-NE. 2002. Boletim estatístico da pesca marítima e estuarina do nordeste do Brasil - 2001. Tamandaré: CEPENE.

Johannes, R. E. 1993. The plight of the osfish, or why the quantitative sophistication is no substitute for asking the right questions. NAGA, 16(1): 4-5.

Koenig, C. C. \& F. C. Coleman. 1998. Absolute abundance and survival of juvenil gags in sea grass beds of the Northeastern Gulf of Mexico. Transactions of the American Fisheries Society, 127: 44-55.

Mabesoone, J. M. \& P. N. Coutinho. 1970. Littoral and shallow marine geology of Northern and Northeastern Brazil. Trabalhos Oceanográficos da Universidade Federal de Pernambuco. Recife, 12: 25-44.

Nagahama, Y. 1983. The functional morphology of teleost gonads. Pp. 223-275 In: Hoar, W. S., D. J. Randall \& E. M. Donaldson (Eds.). Fish Physiology - Reproduction IX (part A). Academic Press, London.
Pickard, G. L. \& W. J. Emery. 1990. Descriptive Physical Oceanography - an introduction. Pergamon Press, Oxford.

Rajasilta, M. 1992. Relationship between food, fat, sexual maturation, and spawning time of Baltic herring (Clupea harengus membras) in the Archipelago Sea. Canadian Journal of Fisheries and Aquatic Sciences, 49: 644-654.

Ricker, W. E. 1969. Effects of size-selective mortality and sampling bias on estimates of growth, mortality, production, and yield. Journal Fisheries Research Board Canadian 26: 479-541.

Roberts, C. M. 1997. Connectivity and management of Caribbean coral reefs. Science, 278: 1454-1457.

Sadovy, Y. J. 1996. Reproduction of reef fishery species. Pp. 15-59. In: Polunin, N. V. C. \& C. M. Roberts (Eds.). Reef fisheries. Chapman \& Hall, London, 477 p.

Sadovy, Y. \& P. L. Colin. 1995. Sexual development and sexuality in the Nassau grouper. Journal of Fish Biology, 46: 961-976.

Sadovy, Y., A. Rosário \& A. Román. 1994. Reproduction in an aggregating grouper, the red hind, Epinephelus guttatus. Environmental Biology of Fishes, 41: 269-86.

Sadovy, Y. \& D.Y. Shapiro. 1987. Criteria for the diagnosis of hermafroditism in fishes. Copeia, 1: 136-156.

Samoilys, M. A. \& L. C. Squire. 1994. Preliminary observations on the spawning behavior of coral trout, Plectropomus leopardus (Pisces: Serranidae), on the Great Barrier Reef. Bulletin of Marine Science, 54(1): 332-342.

Shapiro, D.Y. 1984. Sex reversal and sociodemographic processes in coral reef fishes. Pp. 103-118. In: Poots, G.W. \& R.J. Wooton (Eds.). Fish reproduction: strategies and tactics. Academic Press, Orlando.

Shapiro, D.Y., G. Garcia - Moliner \& Y. Sadovy. 1994. Social system of an inshore stock of the red hind grouper, Epinephelus guttatus (Pisces: Serranidae). Environmental Biology of Fishes, 41: 415-422.

Shapiro, D.Y., Y. Sadovy \& M. A. McGehee. 1993. Periodicity of sex change and reproduction in the red hind, Epinephelus guttatus, a protogynous grouper. Bulletin of Marine Science, 53(3): 1151-1162.

Smith, C. L. 1965. The patterns of sexuality and the classification of serranid fishes. American Museum Novitates, 2207: 1-20.

Smith, C. L. 1972. A spawning aggregation of the Nassau grouper, Epinephelus striatus (Bloch). Transactions of the American Fisheries Society, 101(2): 257-261.

Vazzoler, A. E. A. de M. 1996. Biologia da reprodução de peixes teleósteos: teoria e prática. EDUEM, Maringá, 169p.

Webb, R. O. \& M. J. Kingsford. 1992. Protogynous hermaphroditism in the half-banded sea perch, Hypoplectrodes maccullochi (Serranidae). Journal of Fish Biology, 40: 951-961.

Zar, J. H. 1996. Biostatistical Analysis. Prentice-Hall, New Jersey, 662p + App.

Received August, 2003 Accepted January, 2004 